prof. zw. dr hab. Andrzej H. JASIŃSKI

Wydział Zarządzania, Uniwersytet Warszawski

e-mail:ahj@onet.pl

ORCID: 0000-0001-7433-8803

DOI: $10.15290 /$ oes.2018.03.93.18

\title{
POLITYKA INNOWACYJNA W PROCESIE TRANSFORMACJI W POLSCE: CZY SKUTECZNA?
}

\begin{abstract}
Streszczenie
Głównym celem artykułu jest analiza publicznej polityki innowacyjnej w Polsce w ćwierćwieczu 1990-2015 wraz z próbą oceny skuteczności tej polityki. Omówione są tutaj takie zagadnienia, jak: podstawy współczesnej polityki innowacyjnej, instrumenty polityki innowacyjnej, polityka innowacyjna w Polsce w latach 1990-2015, przyczyny stagnacji innowacyjnej oraz aktualne wyzwania. Nie można, niestety, dać pozytywnej odpowiedzi na pytanie zawarte w tytule.
\end{abstract}

Słowa kluczowe: innowacje, polityka innowacyjna, instrumenty polityki innowacyjnej

\section{INNOVATION POLICY IN THE TRANSFORMATION PROCESS: WAS IT EFFECTIVE?}

\begin{abstract}
Summary
The main aim of this paper is to analyze public innovation policy in Poland in the period from 1990 to 2015 together with an attempt to evaluate the policy effectiveness. The following issues are here presented: the fundamentals of a contemporary innovation policy, innovation policy instruments, Polish innovation policy in 1990-2015, the reasons of an innovation stagnation, and the present policy challenges. Unfortunately, we can not give a positive answer to the question posed in the title.
\end{abstract}

Keywords: innovation, innovation policy, policy instruments

JEL clasification: $\mathrm{O} 31$

\section{Wstęp}

Tytuł niniejszego artykułu można rozumieć dwojako: (1) jako analizę polityki państwa na rzecz innowacji w procesie transformacji polskiej gospodarki, oraz (2) jako analizę procesu transformacji, jaka przeszła publiczna polityka innowacyjna w tymże okresie. Takie właśnie są dwa cele tego opracowania. Podjęta zostanie tutaj próba wykazania, że w latach 1990-2015 polityka innowacyjna w Polsce okazała się małoskuteczna. Zastosowane główne metody badawcze to studia literatury oraz analiza dokumentów źródłowych. 


\section{Podstawy współczesnej polityki innowacyjnej}

We współczesnej gospodarce rynkowej rozwój nauki i techniki odbywa się na różnych poziomach gospodarki. Mamy do czynienia z rozwojem naukowo-technicznym przedsiębiorstwa, branży, regionu, gospodarki narodowej, co pociaga za sobą innowacyjność firm, sektorów, regionów, gospodarek. Rozwój nauki i techniki nie jest jednak procesem samoczynnym, samorealizującym się, lecz podlega zarządzaniu. Tak więc, jest on przedmiotem zarządzania ${ }^{1}$.

Komisja Europejska stwierdza, że konieczna jest poprawa struktury zarządzania innowacyjnością na wszystkich szczeblach gospodarki [EC, 2006]:

- $\quad$ na poziomie narodowym/krajowym: wprowadzenie sprawnych narodowych systemów innowacji (NSI);

- na poziomie regionalnym: włączenie się regionów do sieci dla opracowania i wykorzystania najlepszych praktyk w kluczowych obszarach działania;

- na poziomie firmy: podmioty ekonomiczne muszą być w pełni zaangażowane w wyznaczanie priorytetów polityki innowacyjnej.

Każdy szczebel ma tutaj ważna, choć nieco inną rolę do odegrania. W tym artykule zajmujemy się wyłącznie zarządzaniem na poziomie makro.

Zarządzanie rozwojem nauki i techniki na szczeblu makroekonomicznym to poziom najwyższy, strategiczny. Jednakże trudno jest mówić o „klasycznym” zarządzaniu działalnością innowacyjna, obejmującą również prace badawczo-rozwojowe, na poziomie makro (państwa). Mamy tutaj do czynienia raczej z oddziaływaniem i to pośrednim - instytucji szczebla centralnego na procesy innowacyjne. Państwo (parlament oraz rząd i inne instytucje centralnej administracji państwowej) oddziaływa na działalność innowacyjną m.in. przez: tworzenie przepisów prawa, regulujących tę działalność, wyznaczanie długofalowych kierunków badań naukowych i ustalanie priorytetów w tym zakresie, decyzje finansowe, czyli finansowanie publicznych badań naukowych (placówek, projektów), ogólny nadzór nad funkcjonowaniem publicznych instytucji naukowych oraz realizacja programów i projektów badawczych, wydawanie nakazów lub zakazów związanych np. z ochroną środowiska naturalnego, zdrowia czy bezpieczeństwa użytkowników nowej techniki [Jasiński, 2014]. Należy tu również stosowanie różnych narzędzi polityki innowacyjnej, która jest przejawem interwencjonizmu państwowego.

Wysoki poziom innowacyjności krajów wysokorozwiniętych (KWR) spowodowany jest głównie silnym działaniem mechanizmu konkurencji wśród producentów, który niejako sam przez się wymusza intensywne wprowadzanie nowości technicznych w produkcji i sprzedaży. Takie stwierdzenie byłoby jednak uproszczeniem sprawy, bowiem na źródła sukcesów innowacyjnych składają się tam również: (a) zlokalizowanie większości prac naukowo-badawczych, nakładów finansowych i potencjału badawczo-rozwojowego $(\mathrm{B}+\mathrm{R})$ w przedsiębiorstwach, czyli „blisko rynku”, (b) istnienie szerokiej i zróżnicowanej gamy jednostek krajowego transferu

1 Np. Janasz [1999] pisze w tym kontekście o zarządzaniu postępem naukowo-technicznym w gospodarce narodowej, a Bal-Woźniak [2012] o makroekonomicznym zarządzaniu innowacjami. 
techniki, pośredniczących w przepływie nowych rozwiązań technicznych z wyższych uczelni i instytutów/laboratoriów rządowych do przemysłu (w szerokim rozumieniu tego słowa), (c) otwartość gospodarki, zwłaszcza szeroka międzynarodowa współpraca naukowo-techniczna: duży eksport i import licencji zagranicznych, udział w międzynarodowych programach badawczych, intensywna wymiana naukowców i studentów, (d) wreszcie interwencjonizm państwowy w postaci publicznej polityki innowacyjnej.

Tutaj interesuje nas tylko ta ostatnia przyczyna wysokiej innowacyjności KWR. Chodzi oczywiście o obecność państwa w sferze regulacyjnej, a nie w sferze realnej.

Polityka innowacyjna państwa (publiczna) - traktowana jako zbiór, a właściwie system działań administracji centralnej, wspierających tworzenie, wdrażanie i rozpowszechnianie rozwiązań technicznych - jest to: (1) działalność uprawiana przez jednego z trzech głównych aktorów na scenie innowacji ${ }^{2}$, (2) aktywność dotyczaca narodowego systemu innowacji i jego kształtowania oraz (3) część składowa polityki gospodarczej, ale specyficzna, bo ma w zanadrzu wiele instrumentów pozaekonomicznych. Polityka innowacyjna stanowi jedną z determinant działalności innowacyjnej firm, chociaż główny ciężar prowadzenia tej działalności spoczywa na przedsiębiorstwach.

W literaturze światowej często używa się zamiennie pojęć „,polityka innowacyjna” oraz „polityka naukowo-techniczna”, na którą składają się polityka badawczo-rozwojowa i polityka technologiczna [Edquist, 1994]. Niektórzy nazywaja ją też polityką proinnowacyjna. Jest to de facto polityka promocji innowacji [Malmberg, Maskell, 2010].

W czym należy szukać uzasadnienia dla konieczności prowadzenia państwowej polityki innowacyjnej we współczesnej gospodarce rynkowej? Można by zestawić długą listę argumentów uzasadniających. Dwa z nich są szczególnie ważne [Stoneman, 1987]:

1) suboptymalna alokacja zasobów, wynikająca z, ,rynkowych niedoskonałości”, wydaje się stwarzać racjonalność i wskazówkę dla rządowej polityki interwencji. Owe niedoskonałości powodują, iż mechanizm rynkowy nie jest w stanie wyeliminować takich immanentnych „słabości” procesu innowacji, jak długi okres zwrotu nakładów i wysokie ryzyko;

2) wyższa stopa efektywności społecznej postępu technicznego jest ważnym czynnikiem podkreślającym argumenty na rzecz interwencji rządowej w proces innowacyjnym: mały wzrost zasobów przeznaczonych na innowację może bowiem przynieść wysoką stopę zwrotu³.

2 W modelu sceny innowacji, opartym na koncepcji TripleHelix [Etzkowitz, Leydesdorff, 1995], wystepuje trzech głównych aktorów: rząd (państwo), przemysł w szerokim rozumieniu (sektor biznesu) oraz sektor nauki (sfera B+R) - zob. Jasiński [1997].

3 Jak stwierdzili np. Tidd i Bessant [2011], stopa zwrotu z B+R wynosi blisko 33\%, zysk pojawia się mniej więcej po 5 latach, przy czym innowacje procesowe wykazują 4-krotnie wyższą stopę zwrotu niż innowacje produktowe. 
Można dodać jeszcze jeden dość oczywisty argument na rzecz państwowej polityki innowacyjnej: zbyt dużą rolę w gospodarce odgrywa dzisiaj postęp techniczny i zbyt znaczacy jest to element rozwoju gospodarczego, aby rząd nie interesowal się tym zjawiskiem i nie próbował go wykorzystać do zwiększenia stopy życiowej społeczeństwa. Już bowiem jakiś czas temu szacowano wpływ postępu technicznego na wzrost gospodarczy KWR na około 40\% [Stoneman, 1987], około 1/2 [OECD, 1992], czy ponad 50\% [Linsu, 1999].

Jeśli chodzi o Polskę, co najmniej trzy dodatkowe argumenty przemawiają na rzecz umiejętnej polityki innowacyjnej w okresie transformacji naszej gospodarki [Jasiński, 2006]:

- $\quad$ skoro innowacja techniczna jest zjawiskiem, które we współczesnej, wysoko rozwiniętej gospodarce otrzymuje (w różnych formach) wsparcie rządowe, to również i u nas takie wsparcie powinna otrzymywać;

- zdecydowana większość placówek badawczych i spora część przedsiębiorstw przemysłowych w Polsce, zwłaszcza dużych i średnich, to nadal jednostki państwowe. Należą one do sektora publicznego, za który odpowiada polityka państwa;

- bez aktywnej postawy państwa wobec sfery nauki i techniki nie jest możliwa pełna transformacja polskiej gospodarki i szybkie integrowanie się z Unią Europejska. Siły rynkowe bowiem są u nas nadal zbyt słabe i powolnie działające.

Przyjmujemy za Dodgsonem i Bessantem [1996], że obecnie nadrzędnym celem polityki innowacyjnej jest podniesienie zdolności przedsiębiorstw, gałęzi przemysłu, regionów i całej gospodarki do dokonywania innowacji, a także ułatwianie transferu i rozpowszechniania się innowacji. To dopiero powinno pociagnąc za sobą wzrost konkurencyjności firm, sektorów, regionów, a zatem i gospodarki narodowej jako całości. Aho z zespołem [2006] ujął istotę współczesnej polityki naukowotechnicznej jeszcze krócej i dosadniej - chodzi o wsparcie tworzenia się rynków przyjaznych innowacjom. Obecną politykę innowacyjną w krajach wysokorozwiniętych można by określić jako politykę otwartej, sieciowej i zrównoważonej innowacji, głównie o wymiarze regionalnym.

Główny cel tej polityki można rozbić na trzy cele szczegółowe:

1) regulacyjny, obejmujący różnego typu regulacje wpływające na zdolności innowacyjne;

2) wspierający, zawierający wsparcie finansowe, projektowe, kosztowe itp.;

3) partycypacyjny, finansujący bezpośrednio koszty badań, wdrożeń bądź zamówienia publiczne [Ciborowski, 2016].

Polityka innowacyjna pełni dzisiaj następujące funkcje ${ }^{4}$ [Weresa, 2014]: wzmacnianie powiązań w narodowym systemie innowacji, tworzenie warunków do wdrażania nowych rozwiązań (innowacji), wspieranie zmian strukturalnych w przemyśle

4 Można je rozumieć również jako cele (szczegółowe). 
(szerzej - w gospodarce) oraz umożliwienie przedsiębiorstwom osiagnięcia korzyści z globalizacji i współpracy międzynarodowej.

Rolę współczesnej polityki naukowo-technicznej dobrze tłumaczy tzw. nowa teoria wzrostu [Romer, 1990] w odniesieniu do działalności badawczo-rozwojowej. Teoria ta zakłada, że siły rynkowe nie ustalą optymalnego poziomu B+R ze względu na niedoszacowanie kosztów poniesionych na opracowanie nowych rozwiązań technicznych. Aby zapewnić innowatorom zwrot nakładów, potrzebna jest ochrona patentowa, która daje im monopol na wykorzystanie wynalazku w celach komercyjnych. Ponadto, jak pokazuje model Romera, poza ochrona patentowa potrzebna jest szersza polityka państwa mająca na celu utrzymanie wysokiego poziomu działalności badawczo-rozwojowej. Subsydiowanie zatrudnienia w sektorze B+R, które jest finansowane z podatków, ma podobne skutki dla wzrostu gospodarczego, jak wzrost produktywności tego sektora. W długim okresie subsydiowanie zatrudnienia w tym sektorze spowoduje m.in. przyspieszenie tempa wzrostu gospodarczego, spadek cen nowych rozwiązań technicznych oraz zmniejszenie/poprawienie relacji zasobów zakumulowanego kapitału fizycznego do zasobów zakumulowanej wiedzy. Nie zawsze jednak subsydiowanie działalności badawczo-rozwojowej prowadzi do usunięcia problemu niedoszacowania wartości rynkowej wyników tej działalności i wynikającej z tego niewystarczającej podaży nowych idei. Zamiast subsydiowania prac B+R proponuje się wówczas subsydiowanie zakupów wyników $\mathrm{B}+\mathrm{R}$ po cenach wyższych niż rynkowe [Weresa, 2012].

„Filozofia” współczesnej polityki innowacyjnej jest następująca: dzięki innowacjom dokonuje się postęp techniczny w gospodarce. Motorem tego postępu nie jest dzisiaj naukowiec/zespół badawczy/placówka B+R, lecz innowacyjnie zorientowany przedsiębiorca. Przede wszystkim od niego zależy, czy postęp techniczny będzie mieć miejsce w (jego) przedsiębiorstwie, a więc i w całej gospodarce. Firma jest niejako naturalnym miejscem, gdzie pojawiają się innowacje. Natomiast jednostki naukowe należy traktować jako otoczenie przedsiębiorstwa. To one powinny odgrywać służebną rolę wobec przedsiębiorcy, a nie odwrotnie. Stąd firma, zwłaszcza mała czy średnia, jest „,oczkiem w głowie” tej polityki.

Polityka innowacyjna - jak każda polityka publiczna - powinna nie tylko wyznaczyć konkretne cele (średnio- i krótkookresowe), ale także zapewnić i uruchomić środki dla ich realizacji w określonych, np. rocznych, odcinkach czasu. Wzrost innowacyjności gospodarki, jako rezultat owej polityki, powinien spowodować wzrost poziomu konkurencyjności dóbr wytwarzanych w danym kraju. Chodzi tu przede wszystkim o konkurencyjność pozacenową, czyli o konkurowanie nowościa, nowoczesnością, jakością.

Jednakże bieżąca polityka powinna wynikać z długofalowej strategii naukowotechnicznej kraju. Z kolei podstawą opracowania tej strategii powinien być tzw. foresight. Foresight jest to społeczny proces systematycznego i wszechstronnego rozpoznawania dalekosiężnych trendów rozwojowych oraz identyfikacji obszarów w nauce i technice o kluczowym znaczeniu dla maksymalizacji korzyści społecznych i gospodarczych [Bendyk, 2010]. Na tej podstawie następuje określanie i uzgadnianie 
kierunków dalszych badań naukowych i prac rozwojowych w długim okresie. ${ }^{5}$ Tak więc pożądany mechanizm jest tu następujący:

\section{Foresight $\rightarrow$ Strategia $\rightarrow$ Polityka $\rightarrow$ Innowacyjność $\rightarrow$ Konkurencyjność}

Politykę innowacyjną winno charakteryzować $\mathbf{6 K}$, tzn. powinna być:

- $\quad$ koordynowana - między instytucjami rządowymi odpowiedzialnymi za rozwój nauki i techniki, przy czym jedna z nich powinna odgrywać czołowa rolę,

- $\quad$ konsekwentna - stabilna w dłuższym okresie,

- $\quad$ korelowana - polityka badawczo-rozwojowa zintegrowana z technologiczna,

- kompleksowa - obejmująca polityki na rzecz B+R (zwłaszcza w firmach), innowacyjności sektora małych i średnich przedsiębiorstw (MŚP), transferu techniki, ochrony własności intelektualnej,

- kompatybilna - dopasowana do polityki ekonomicznej państwa,

- $\quad$ koherentna - spójna z polityką Unii Europejskiej [Jasiński, 2006].

\section{Instrumenty polityki innowacyjnej}

Instrumentarium współczesnej polityki innowacyjnej jest bardzo szerokie. W oparciu o przegląd literatury światowej sporządzony został długi zestaw środków stosowanych przez administrację centralną do stymulowania innowacji technicznych [Klincewicz, 2008]: granty badawcze tworzace system finansowania publicznych instytutów i uczelni, subsydiowanie działalności badawczo-rozwojowej przedsiębiorstw, zamówienia publiczne na nowe produkty finansujące dalszy ich rozwój, system zachęt finansowych umożliwiających odpis kosztów $\mathrm{B}+\mathrm{R}$ od przychodów oraz inne ulgi podatkowe, tworzenie konsorcjów badawczych, laboratoriów narodowych i parków naukowo-technologicznych, promowanie współpracy między publicznymi instytucjami badawczymi a firmami, oferowanie usług doradztwa technicznego i biznesowego dla firm innowacyjnych, a także doskonalenie systemu szkolnictwa wyższego, nastawione na stymulowanie zaawansowanych badań w istotnych dla gospodarki dziedzinach nauki. Jeszcze dłuższą listę 16 narzędzi tej polityki sporządził Czerniak [2013]. Długi zbiór narzędzi można znaleźć np. w dokumentach OECD [1997].

Instrumenty polityki naukowo-technicznej można klasyfikować według rożnych kryteriów (zob. tabela 1).

Zatrzymajmy się przy tym ostatnim podziale, który ma tutaj zasadnicze znaczenie. Wynika ono stąd, że niektóre instrumenty finansowe stanowią jednocześnie źródła finansowania działalności innowacyjnej firm. Należy przy tym oczywiście

5 W Polsce Narodowy Program Foresight „Polska 2020” został zakończony w roku 2009 - zob. dalej. 
pamiętać, iż stymulowanie innowacji nie jest tylko kwestią pieniędzy. Stąd występuje stosunkowo szeroka gama instrumentów niefinansowych.

Finansowanie działalności innowacyjnej ze środków publicznych odejmuje dwa podstawowe typy nakładów: (1) bezpośrednie nakłady budżetowe (głównie subsydia i granty) oraz (2) tzw. nakłady podatkowe (instrumenty podatkowe), jak ulgi, zwolnienia i ,wakacje” podatkowe. Oba typy instrumentów mają i zalety, i wady. Uważa się przy tym, że w krajach wysokorozwiniętych subsydia (granty) stanowią znacznie silniejszą ingerencję w funkcjonowanie mechanizmu rynkowego, ale są bardziej skuteczne niż narzędzia podatkowe. Niektórzy zaś odwrotnie uważaja, iż to właśnie ulgi w podatkach są tu lepszym narzędziem, bo mają charakter systemowy (nie indywidualny) oraz nie „psują" mechanizmu konkurencji. Jak piszą np. Guellec i van Pottelsberghe [2003], ulgi podatkowe i subsydia są względem siebie substytucyjne, tzn. że zwiększenie zakresu stosowania jednego instrumentu zmniejsza skuteczność drugiego. Trzeba również pamiętać o możliwych negatywnych efektach zwiększania bezpośrednich nakładów budżetowych, jak np. zjawiska wypierania środków prywatnych (firm) przez środki publiczne, czy kredytów przez „darmowe” dotacje i subsydia. Szeroka, interesującą dyskusję nad rolą zachęt podatkowych do innowacji w Polsce znajdujemy w pracy Czerniaka [2013].

TABELA 1

Klasyfikacja instrumentów polityki innowacyjnej

\begin{tabular}{|c|c|}
\hline Kryterium klasyfikacji & Wyszczególnienie \\
\hline Szczebel wsparcia & $\begin{array}{l}\text { a) szczebel centralny: parlament, rząd, naczelne organy } \\
\text { administracji państwowej, inne instytucje rządowe, } \\
\text { b) szczebel regionalny/wojewódzki, } \\
\text { c) szczebel lokalny (jednostki samorządu terytorialnego) }\end{array}$ \\
\hline $\begin{array}{l}\text { Adresaci działań } \\
\text { państwa }\end{array}$ & $\begin{array}{l}\text { firmy (komercyjne) z podziałem na: małe i średnie } \\
\text { przedsiębiorstwa (MŚP) oraz duże i wielkie przedsiębiorstwa } \\
\text { (DWP), } \\
\text { b) instytucje naukowo-badawcze (uczelnie i placówki B+R), } \\
\text { c) pozostałe organizacje, w tym instytucje otoczenia biznesu } \\
\text { (IOB) }\end{array}$ \\
\hline $\begin{array}{l}\text { Sposób oddziaływania } \\
\text { na firmę }\end{array}$ & $\begin{array}{l}\text { oddziaływanie bezpośrednie - granty, zachęty finansowe, pro- } \\
\text { gramy i projekty rządowe, zamówienia publiczne, } \\
\text { b) oddziaływanie pośrednie - regulacje prawne i instrumenty po- } \\
\text { mostowe }\end{array}$ \\
\hline $\begin{array}{l}\text { Stadium rozwoju } \\
\text { podmiotu-beneficjenta }\end{array}$ & $\begin{array}{l}\text { a) dla istniejacych podmiotów, } \\
\text { b) dla nowotworzonych podmiotów, w szczególności start- } \\
\text { up'ów }\end{array}$ \\
\hline $\begin{array}{l}\text { Rynkowy charakter od- } \\
\text { działywania }\end{array}$ & $\begin{array}{l}\text { a) narzędzia popytowe oddziałujące na popyt zgłaszany na nowe } \\
\text { rozwiązania techniczne, głównie ze strony przedsiębiorstw, }\end{array}$ \\
\hline
\end{tabular}

6 Tutaj zajmujemy się tylko narzędziami tworzonymi i stosowanymi przez administrację centralną. 


\begin{tabular}{|c|c|}
\hline Kryterium klasyfikacji & Wyszczególnienie \\
\hline & $\begin{array}{l}\text { b) narzędzia podażowe oddziałujące na podaż nowych rozwią- } \\
\text { zań technicznych, oferowana głównie przez instytucje sektora } \\
\text { B+R; chodzi tu przede wszystkim o publiczne nakłady na } \\
\text { B }+\mathrm{R}\end{array}$ \\
\hline $\begin{array}{l}\text { Źródła finansowania in- } \\
\text { strumentów }\end{array}$ & $\begin{array}{l}\text { a) ze środków krajowych (budżet państwa), } \\
\text { b) ze środków unijnych i innych z zagranicy, }\end{array}$ \\
\hline $\begin{array}{l}\text { Ekonomiczny charakter } \\
\text { narzędzi }\end{array}$ & $\begin{array}{l}\text { a) finansowe narzędzia, } \\
\text { b) pozafinansowe narzędzia, w tym regulacje (prawne). }\end{array}$ \\
\hline
\end{tabular}

Źródło: opracowanie własne.

Dużo bardziej zróżnicowaną grupę instrumentów stanowią bezpośrednie nakłady budżetowe, czyli innymi słowy: publiczne źródła dofinansowania. Można tutaj bowiem rozróżnić cztery podgrupy: a) subsydia (dotacje) zwykle w formie grantu, czyli płatności bezzwrotne, b) kredyty ${ }^{7}$, gwarancje i ubezpieczenia, c) zamówienia (zakupy) publiczne oraz d) inne, np. udziały kapitałowe Skarbu Państwa w funduszach typu Venture Capital (VC).

W literaturze polskiej zostały szeroko zaprezentowane doświadczenia różnych krajów europejskich w zakresie stosowania narzędzi polityki innowacyjnej - zob. np. prace zbiorowe pod redakcja Janasza [2010, 2011] oraz opracowania Czerniaka [2013], Jasińskiego [1997], Kozioł [2007] oraz Weresy [2014].

Biorąc pod uwage polskie doświadczenia na tle doświadczeń zagranicznych, proponujemy poniższą klasyfikację narzędzi polityki innowacyjnej stosowanych w Polsce:

1. regulacje (prawne), w tym zwłaszcza państwowe zakazy, nakazy, limity, normy, standardy oraz przepisy dotyczące ochrony środowiska naturalnego, konkurencji, konsumenta i własności intelektualnej, które łącznie tworzą swego rodzaju warunki brzegowe dla działań różnych podmiotów w zakresie innowacji. Należy tutaj z pewnością dopisać regulacje dotyczące partnerstwa publiczno-prywatnego (PPP);

2. instrumenty systemowe („urzędowe”), czyli zachęty finansowe zapisane w ustawach, które maja zachęcać firmy do działalności innowacyjnej;

3. programy i projekty rządowe, w tym również zamówienia publiczne, ogłaszane na dany okres i ukierunkowane na realizację konkretnych celów/ zadań polityki państwa w tym okresie;

4. instrumenty (rozwiazania) pomostowe, mające charakter wsparcia dla instytucji pośredniczacych w procesach innowacyjnych. Chodzi tutaj o swoiste „wsparcie (dla firm) poprzez wsparcie” dla instytucji otoczenia biznesu. Narzędzia te są czasem nazywane organizatorskimi lub instytucjonalnymi.

Jak widać, państwo ma dziś do dyspozycji szeroki, zróżnicowany zestaw narzędzi wsparcia działalności innowacyjnej. Dobór instrumentów polityki innowacyjnej za-

7 Tylko jeśli kredytu udziela bank państwowy. 
leży m.in. od celów stawianych pod jej adresem na dany okres oraz zasobów finansowych „wygospodarowanych” na ten okres. Zauważmy przy tym, iż część zasobów publicznych przeznaczanych na tę działalność może pochodzić z zagranicy - tak jak to się dzieje obecnie w przypadku Polski.

\section{Polityka innowacyjna w Polsce, 1990-2015}

O rozmiarach interwencjonizmu państwowego w dziedzinie nauki i techniki świadczy przede wszystkim wysiłek finansowy państwa w tej sferze. Skala wydatków budżetowych jest bowiem rezultatem decyzji politycznych. Zobaczmy zatem, jak kształtowały się nakłady budżetowe na B+R i innowacje w Polsce w latach 19902015 (tabela 2).

TABELA 2

Podstawowe wskaźniki nakładów na B+R i innowacje w Polsce
w latach 1990-2015 (w \%)

\begin{tabular}{|l|c|c|c|c|c|c|}
\hline & $\mathbf{1 9 9 0}$ & $\mathbf{1 9 9 5}$ & $\mathbf{2 0 0 0}$ & $\mathbf{2 0 0 5}$ & $\mathbf{2 0 1 0}$ & $\mathbf{2 0 1 5}$ \\
\hline Nakłady na B+R jako \% PKB & 0,96 & 0,69 & 0,64 & 0,57 & 0,74 & 1,00 \\
\hline $\begin{array}{l}\text { Nakłady budżetowe } \\
\text { na B+R jako \% PKB }\end{array}$ & - & 0,47 & 0,44 & 0,29 & 0,34 & 0,44 \\
\hline $\begin{array}{l}\text { Udział budżetu w nakładach } \\
\text { firm na innowacje }(\mathrm{w} \%)^{8}\end{array}$ & - & - & 1,50 & 1,70 & 1,00 & 1,80 \\
\hline
\end{tabular}

Źródło: Roczniki w serii Nauka i Technika, GUS, kolejne lata.

Jak widać, wysiłek finansowy państwa, mierzony procentowym udziałem nakładów budżetowych na B+R w produkcie krajowym brutto (PKB), kurczył się do 2005 roku, a następnie zaczął powoli rosnać. Zresztą takie same tendencje dotyczyły kształtowania się całkowitych nakładów na B+R (z ang. Gross Expenditure on Research and Development - GERD) w relacji do PKB. W rezultacie w końcu badanego okresu wróciliśmy do poziomu sprzed 25 lat.

Dla porównania zauważmy, że w 2015 roku cztery kraje Unii Europejskiej (Szwecja, Finlandia, Austria i Dania) przekroczyły 3-procentowy próg jako tzw. cel barceloński ${ }^{9}$ wyznaczony w Strategii Lizbońskiej UE z 2000 roku. Polska (1\% w roku 2015) zajmowała wówczas mniejwięcej 6-8 miejsce od końca tabeli (razem z Bułgarią i Grecja), przy średniej unijnej nieco ponad 2\% [GUS, 2016].

Natomiast jeśli chodzi o wysiłek finansowy państwa w zakresie działalności innowacyjnej, to kształtował się on na poziomie 1,5-1,8\% nakładów firm przemysło-

8 Chodzi tu o procentowy udział środków budżetu państwa w nakładach przedsiębiorstw przemysłowych (zatrudniajacych powyżej 49 pracowników) na działalność innowacyjna.

9 Chodzi o udział GERD w PKB. 
wych na tę działalność. W 2010 roku wynosił jeszcze mniej, bo zaledwie 1\%. Można zatem powiedzieć, że w latach 2000-2015 budżet państwa praktycznie nie angażował się $\mathrm{w}$ działania innowacyjne przedsiębiorstw.

Za politykę innowacyjna w Polsce w początkowym okresie transformacji odpowiedzialny był przede wszystkim Komitet Badań Naukowych (KBN), chociaż w ustawie o jego utworzeniu [Dz. U. Nr 8 z 1991 r.] nie było słowa ,innowacje”. Pewna, choć niewielka rola była i nadal jest pełniona w tym względzie przez quazirządową Fundację na rzecz Nauki Polskiej oraz przez, już dziś nie istniejąca, Agencję Techniki i Technologii, a obecnie przez Polską Agencję Rozwoju Przedsiębiorczości (PARP). Również Ministerstwo Gospodarki podejmowało inicjatywy dotyczące wspierania procesów innowacji i transferu techniki. W Ministerstwie tym przygotowano szereg programów rządowych $\mathrm{w}$ tym obszarze, m.in. program na rzecz małych i średnich przedsiębiorstw, program zwiększania innowacyjności polskiej gospodarki, ustawę o wspieraniu innowacji. Jednakże inicjatywy te nie były dostatecznie skoordynowane z dokumentami opracowywanymi w KBN, głównie dlatego, że nie było jasnego podziału kompetencji między Ministerstwem a Komitetem w prowadzeniu polityki naukowo-technicznej.

Z dniem 1.04.2003 r., głównie na bazie KBN, utworzono Ministerstwo Nauki i Informatyzacji, obecnie Ministerstwo Nauki i Szkolnictwa Wyższego (MNiSW), jako organ decydujący przede wszystkim o rozdziale środków budżetowych na badania naukowe i prace rozwojowe. Natomiast zgodnie z ustawą o zasadach finansowania nauki [Dz. U. Nr 238 z 2004 r.], z dniem 5.02.2005 r. w miejsce KBN została powołana Rada Nauki, obecnie Komitet Polityki Naukowej, jako ciało opiniodawczo-doradcze Ministra. Ostatnio zdecydowaną większość decyzji dotyczących finansowania prac $\mathrm{B}+\mathrm{R}$ przekazano dwóm agencjom MNiSW, tj. Narodowemu Centrum Badań i Rozwoju (NCBiR) w Warszawie (utworzonemu w 2007 r.) oraz Narodowemu Centrum Nauki (NCN) w Krakowie (utworzonemu w 2010 r.). Nadal jednak nie ma jednego organu rządowego, który byłby w pełni odpowiedzialny za formułowanie i wdrażanie polityki innowacyjnej.

Punkt zwrotny miał miejsce na przełomie lat 2007-2008, kiedy nastąpiło swego rodzaju nowe otwarcie związane $z$ rozpoczętym napływem do Polski olbrzymich środków finansowych z funduszy unijnych. W tym samym momencie zaczął się jednak ogólnoświatowy kryzys gospodarczy, który dotkną również polską gospodarkę.

Z analizy dokumentów przyjętych przez Radę Ministrów przed „nowym otwarciem" wynika ${ }^{10}$, iz instrumenty polityki innowacyjnej w latach 1990-2007 cechowały się tym, że:

- zdecydowaną większość stanowiły narzędzia finansowe; pozostałe rodzaje możliwych przedsięwzięć były niedoceniane,

- $\quad$ wyraźnie dominowały instrumenty strony podażowej nad popytowa,

- większość z nich była adresowana do przedsiębiorstw (przemysłu) jako całości,

10 Wykaz tych dokumentów wraz ze szczegółowymi wynikami ich analizy zawarty jest w pracy Jasińskiego [2006]. 
- brakowało narzędzi adresowanych do sektorów (branż) wysokiej techniki,

- zbyt duży nacisk był położony na wsparcie tworzenia nowych osiagnięć naukowych zamiast na ich wdrażanie,

- instrumenty wspierania innowacji były zorientowane raczej na generowanie innowacji niż na ich dyfuzję; trudno wśród nich znaleźć takie narzędzia, które byłyby „wycelowane” wyłącznie w transfer techniki.

W latach 1990-2007 można rozróżnić pięć okresów/faz w naszej polityce naukowo-technicznej (zob. tabela 3).

Jak widać, miało miejsce swoiste falowanie bieżącej polityki innowacyjnej. Była to krótko-okresowa polityka. Główną przyczyną takiego stanu rzeczy był brak długoterminowej strategii rozwoju nauki i techniki dla okresu transformacji ustrojowej. Można więc mówić o następujących cechach polityki naukowo-technicznej w latach 1990-2007: brak długookresowej strategii rozwoju nauki i techniki, falowanie bieżącej polityki, niedostateczna koordynacja działań między agendami rządowymi, relatywny spadek nakładów budżetowych na $\mathrm{B}+\mathrm{R}$, dość silna centralizacja polityki, zwłaszcza finansowania badań naukowych i brak regionalnego podejścia, zbyt małe wsparcie dla badań stosowanych w ramach decyzji finansowych, za duży nacisk położony na wsparcie nauki jako takiej zamiast na innowacje per se oraz brak polityki na rzecz transferu techniki/dyfuzji innowacji.

TABELA 3

Fazy polityki innowacyjnej w Polsce w latach 1990-2015

\begin{tabular}{|l|l|l|}
\hline $\begin{array}{c}\text { Faza } \\
\text { nr }\end{array}$ & \multicolumn{1}{|c|}{ Lata } & \multicolumn{1}{c|}{ Charakterystyka polityki } \\
\hline 1 & $\begin{array}{l}\text { Do roku } \\
1990\end{array}$ & $\begin{array}{l}\text { Na przełomie lat } \\
\text { jako rozwiązań prawnych adresowanych do przedsiębiorstw, zwłaszcza } \\
\text { małych, dla stymulowania ich działalności badawczej i innowacyjnej. }\end{array}$ \\
\hline 2 & $\begin{array}{l}1991- \\
1994\end{array}$ & $\begin{array}{l}\text { W ramach tzw. planu Balcerowicza i powszechnej wiary w rolę ,niewidzial- } \\
\text { nej ręki rynku”, zlikwidowano zdecydowaną większość owych stymulatorów. }\end{array}$ \\
\hline 3 & $\begin{array}{l}1995- \\
1999\end{array}$ & $\begin{array}{l}\text { Z poczattkiem 1995 r. przywrócono jednak niektóre ze „starych” zachęt } \\
\text { dla działalności badawczo-rozwojowej i innowacyjnej; lista podatkowych } \\
\text { preferencji była nawet dość długa. }\end{array}$ \\
\hline 4 & $\begin{array}{l}2000- \\
2004\end{array}$ & $\begin{array}{l}\text { Na poczatku 2000 r., pod wpływem trudności z budżetem państwa, } \\
\text { ponownie ograniczono liczbę zachęt, a nowych nie wprowadzono. }\end{array}$ \\
\hline 5 & $2005-$ & $\begin{array}{l}\text { W roku 2005, w związku z przystapieniem do Unii Europejskiej, wprowa- } \\
\text { dzono kilka istotnie nowych rozwiazań/instrumentów i ponownie przy- } \\
\text { wrócono niektóre z poprzednio obowiązujących narzędzi podatkowych. }\end{array}$ \\
\hline 6007 & $\begin{array}{l}2008- \\
2015\end{array}$ & $\begin{array}{l}\text { Nowe instrumentarium oparte na wykorzystaniu znaczących środków } \\
\text { z funduszy unijnych }\end{array}$ \\
\hline
\end{tabular}

Źródło: opracowanie własne. 
Była to bardziej polityka naukowa niż techniczna - swoista mieszanka: z jednej strony, jeszcze funkcjonował model typu science-push, ale stawał się coraz słabszy; z drugiej strony zaś zaczął funkcjonować model typu market-pull, a następnie model interaktywny ${ }^{11}$. Polityka ta cały czas ewoluowała.

Jednakże nie zaobserwowaliśmy jakiejś wyraźnej zależności między aktywnością innowacyjną w gospodarce a polityką innowacyjna. Wprawdzie dokonania innowacyjne ( $\mathrm{z}$ ang. innovation performance) też charakteryzowały się falowaniem, ale niezależnie od faz w polityce naukowo-technicznej. Mianowicie, dokonania te niejako podążały (z jedno- dwuletnim opóźnieniem) za dynamiką makroekonomiczną ${ }^{12}$. Można stwierdzić, że w latach 1990-2007 postęp techniczny w Polsce odbywał się raczej pod wpływem (a) regulacji makro-ekonomicznych, (b) sił rynkowych i (c) napływu zagranicznej myśli technicznej niż pod wpływem polityki naukowo-technicznej państwa. (Nie była ona zresztą kompatybilna z polityką makro-ekonomiczna). Okazało się więc, że innowacje są równie podatne na politykę makro-ekonomiczną i ogólną sytuację gospodarczą kraju, jak na politykę innowacyjna.

Polska polityka na rzecz innowacji w badanym okresie spotkała się z ostrą krytyką ze strony wielu autorów (zob. np. Czerniak [2013]; Janasz i Kozioł-Nadolna [2011]; Jasiński [2006]; Klincewicz [2008]; Marciniak 2010]; Moszkowicz [2001]; Okoń-Horodyńska [1998]). Chyba najbardziej kategorycznie stwierdziła Bal-Woźniak: „Przerwanie błędnego koła niskich skłonności do zachowań innowacyjnych jest powinnością państwa” [Bal-Woźniak, 2012, s. 232]. W pełni zgadzamy się z tą ocena.

Wspomniane „nowe otwarcie” w polityce naukowo-technicznej nastapiło dopiero na przełomie lat 2007-2008. Otóż, w 2007 roku rząd wprowadził w życie Narodową Strategię Spójności (NSS), która służyła wykorzystaniu środków finansowych przeznaczonych dla Polski z unijnych Funduszy Strukturalnych i Funduszu Spójności w ramach tzw. perspektywy finansowej UE na lata 2007-2013. Na Strategię tę składało się siedem ogólnokrajowych programów operacyjnych oraz 16 regionalnych/wojewódzkich programów operacyjnych. Za ich realizację odpowiadało ówczesne Ministerstwo Rozwoju Regionalnego (MRR).

Jednym z tych programów był Program Operacyjny „Innowacyjna Gospodarka" (POIG), na który przeznaczono 9,71 mld Euro, z tego 8,25 mld Euro (85\%) z funduszy unijnych oraz 1,46 mld Euro (15\%) z budżetu państwa. Główny cel POIG zdefiniowano dość ogólnikowo jako: rozwój polskiej gospodarki w oparciu o innowacyjne przedsiębiorstwa $\left[\right.$ MRR, 2007] ${ }^{13}$. Cel ten wynikał wprost ze strategicznego celu NSS, który brzmiał dużo lepiej, a mianowicie: tworzenie warunków dla wzrostu konkurencyjności gospodarki polskiej opartej na wiedzy i przedsiębiorczości, zapewniającego wzrost zatrudnienia oraz poziomu spójności społecznej, gospodarczej i przestrzennej.

11 Więcej o tych modelach innowacji - zob. Jasiński [1997]. O tych i innych modelach pisze też np. Ciborowski [2012].

12 Szerszy wywód na ten temat - zob. Jasiński [2006, s. 189-190 i 204-206].

13 Niektóre projekty innowacyjne można było realizować również w ramach innych programów operacyjnych. 
Główny cel POIG został rozpisany na sześć celów szczegółowych, a całość podzielona na osiem tzw. osi priorytetowych. Około 90\% środków finansowych poszło na trzy obszary: (1) badania i rozwój, (2) innowacje oraz (3) technologie informacyjne i komunikacyjne [MRR, 2007]. W obszarze „Innowacje” preferowane były małe i średnie przedsiębiorstwa.

Program Operacyjny „Innowacyjna Gospodarka” stanowił rzeczywisty przełom w polityce państwa na rzecz innowacji, choć był realizowany głównie ze środków zagranicznych, które napływały w latach 2008-2015. Szczęśliwie dla Polski realizacja tego programu przypadła na okres wyraźnego spowolnienia rozwoju gospodarki narodowej pod wpływem światowego kryzysu gospodarczego. Z powodu kryzysu wiele polskich firm ograniczyło własne nakłady na działalność innowacyjna, które zostały w dużym stopniu zastąpione przez fundusze unijne [Jasiński, 2018].

Równolegle do POIG stosowane były również inne narzędzia wsparcia działalności innowacyjnej firm, finansowane ze środków krajowych, tj. z budżetu państwa, m. in.:

- instrumenty systemowe: odpis wydatków na B+R od podstawy podatku dochodowego, ulga technologiczna, kredyt technologiczny ${ }^{14}$,

- programy rządowe realizowane przez PARP (Pożyczka na Innowację, Bon na Innowacje, Wsparcie na Uzyskanie Grantu) oraz przez NCBiR takie, jak programy: badań stosowanych, projektów celowych i projektów rozwojowych oraz osiem programów wspierających wdrażanie, komercjalizację i współpracę między firmami,

- instrumenty/rozwiązania pomostowe: narzędzia wsparcia finansowego dla tzw. instytucji pomostowych należących do sektora instytucji otoczenia biznesu (IOB). W tym przypadku chodzi zwłaszcza o podmioty/osoby należące do Stowarzyszenia Organizatorów Ośrodków Innowacji i Przedsiębiorczości w Polsce (SOOIPP),

- regulacje prawne - po dostosowaniu polskiego prawa do standardów i wymogów Unii Europejskiej przed przystapieniem do niej, działania regulacyjne rządu polegały tutaj przede wszystkim na ciagłym doskonaleniu przepisów zawartych w Ustawie o niektórych formach wspierania dz̨iałalności innowacyjnej z 2008 roku.

Lata 2008-2015 można określić jako szósty okres w polityce innowacyjnej Polski. Jego rozpoczęcie zbiegło się w czasie z zakończeniem w 2008 r. Narodowego Programu Foresight (NPF) „Polska 2020”, sfinansowanego ze środków Ministerstwa Nauki i Szkolnictwa Wyższego. Celem NPF było: (1) określenie wizji rozwojowej Polski do 2020 r., (2) zbliżenie zasad polskiej polityki naukowo-technicznej do wymogów Unii Europejskiej i (3) ukształtowanie tej polityki w kierunku gospodarki opartej na wiedzy (GOW). W efekcie realizacji Programu opracowano [Bendyk, 2010]:

- pięć zintegrowanych scenariuszy rozwoju Polski do 2020 r.,

14 Ten ostatni został po kilku latach stosowania „przejęty” przez PO „Innowacyjna Gospodarka”. 
- bardzo długa listę makrotematów (114) i priorytetów badawczo-rozwojowych (aż 680),

- $\quad$ zestaw czterech czynników o kluczowym znaczeniu dla przyszłego rozwoju Polski, tj. integrację międzynarodowa, reformy wewnętrzne, akceptację społeczną oraz właśnie gospodarkę opartą na wiedzy,

- rekomendacje pod adresem polityki państwa, które ujęto w trzy grupy. Otóż, polityka naukowo-techniczna powinna polegać na: 1) rozwoju badań i technologii stwarzających największe szanse gospodarcze lub mających istotne znaczenie strategiczne, 2) rozwoju badań i technologii o charakterze horyzontalnym (jak np. teleinformatyka), tworzących płaszczyznę dla powstawania i dystrybucji innowacji oraz 3) wspieraniu badań społeczno-ekonomicznych majacych na celu lepsze zrozumienie społecznego kontekstu polityki rozwojowej.

Ocena szóstego okresu nie jest jednoznaczna, a mianowicie:

- $\quad$ wyniki foresight'u były w niezadowalającym stopniu wykorzystane w polityce innowacyjnej, ponieważ Narodowa Strategia Spójności została przyjęta dwa lata przed ogłoszeniem rezultatów NPF „Polska 2020”,

- nie stwierdzono istotnych statystycznie zależności między poziomem innowacyjności polskich firm przemysłowych a dopływem środków z Funduszy Strukturalnych Unii Europejskiej [Jasiński, 2018]. Nie spełniły się zatem wielkie „oczekiwania innowacyjne”, jakie dość powszechnie zapanowały w Polsce na początku Perspektywy Finansowej 2007-2013. W związku z napływem tych funduszy pojawiły się natomiast niekorzystne zjawiska, które wymieniono w punkcie 2 niniejszego artykułu,

- nakłady budżetowe (w cenach bieżących) na działalność innowacyjną firm przemysłowychw (trzech kolejnych latach (2009-2011) wyraźnie przyhamowały. Notabene, w tym samym czasie nakłady ze środków unijnych szybko i znacząco rosły [Jasiński, 2018]. Następnie w roku 2012 miał miejsce wzrost wydatków z budżetu państwa, by w kolejnym roku znów spaść do poziomu z roku wyjściowego (2008). Tymczasem płatności z Unii nadal rosły ${ }^{15}$. Dopiero w ostatnim roku badanego okresu nakłady budżetowe znacznie wzrosły. Jak widać, rząd uzależnił swoje wsparcie dla aktywnych innowacyjnie firm od napływu środków z funduszy UE.

\section{Przyczyny stagnacji innowacyjnej}

W drugiej połowie okresu 2008-2015, zamiast spodziewanych ,żniw” innowacyjnych pojawiła się stagnacja innowacyjna. Wskazują na to chociażby dane zawarte

15 Według danych GUS [2016]:

\begin{tabular}{|l|c|c|c|c|c|c|c|c|}
\hline Wyszczególnienie & $\mathbf{2 0 0 8}$ & $\mathbf{2 0 0 9}$ & $\mathbf{2 0 1 0}$ & $\mathbf{2 0 1 1}$ & $\mathbf{2 0 1 2}$ & $\mathbf{2 0 1 3}$ & $\mathbf{2 0 1 4}$ & $\mathbf{2 0 1 5}$ \\
\hline Płatności z Unii Europejskiej [mld zł] & 0,28 & 0,17 & 0,23 & 0,23 & 0,39 & 0,28 & 0,36 & 0,52 \\
\hline
\end{tabular}


w tabeli 4. W rezultacie, biorąc pod uwagę syntetyczny wskaźnik innowacyjności (z ang. Summary Innovation Index - SII), w 2015 roku Polska zajmowała 25 lokatę wśród 28 krajów członkowskich UE, czyli spadła o dwa miejsca w stosunku do roku 2009 [EC, 2010 i 2016].

TABELA 4

Innowacyjność przedsiębiorstw przemysłowych w latach 2008-2015 (w\%)

\begin{tabular}{|l|c|c|c|c|c|c|c|c|}
\hline & $\mathbf{2 0 0 8}$ & $\mathbf{2 0 0 9}$ & $\mathbf{2 0 1 0}$ & $\mathbf{2 0 1 1}$ & $\mathbf{2 0 1 2}$ & $\mathbf{2 0 1 3}$ & $\mathbf{2 0 1 4}$ & $\mathbf{2 0 1 5}$ \\
\hline $\begin{array}{l}\text { Odsetek firm innowacyjnych } \\
\text { w przemyśle }\end{array}$ & 21,4 & 18,1 & 17,1 & 16,1 & 16,5 & 17,1 & 17,5 & 17,6 \\
\hline $\begin{array}{l}\text { Odsetek firm, które wprowadziły } \\
\text { produkty nowe w skali kraju }\end{array}$ & 9,4 & 7,0 & 6,8 & 6,1 & 5,6 & 5,7 & 6,2 & 6,5 \\
\hline $\begin{array}{l}\text { Udział przychodów ze sprzedaży } \\
\text { nowości w przychodach netto } \\
\text { w przemyśle }\end{array}$ & 12,4 & 10,6 & 11,3 & 8,9 & 11,5 & 10,7 & 10,8 & 11.6 \\
\hline
\end{tabular}

Źródło: Roczniki w serii Nauka i Technikea, GUS, kolejne lata.

Jeśli więc za kryterium oceny polityki innowacyjnej przyjać miejsce danego kraju w rankingu innowacyjności państw - członków Unii, można powiedzieć ze polska polityka w latach 2008-2015 była raczej nieskuteczna. Wielce krytyczną ocenę naszej polityki naukowo-technicznej w tym okresie można znaleźć w pracach np. Czerniaka [2013], Świadka [2017], Weresy [2014].

Przyczyn owej stagnacji należy upatrywać wśród utrzymujących się nadal strukturalnych słabości/niesprawności polskiej gospodarki, takich jak to, że $\mathrm{e}^{16}$ :

1. sektor badań i rozwoju $(B+R)$, obejmujący uczelnie, instytuty PAN i pozostałe instytuty badawcze, jest nadal w zdecydowanej większości państwowy, a więc w pełni zależny od finansów publicznych;

2. prawie $80 \%$ polskiego potencjału $\mathrm{B}+\mathrm{R}$, mierzonego liczbą pracowników naukowo-badawczych, tkwi w tym sektorze. Oznacza to, że ok. 80\% „produkcji naukowej" powstaje poza przedsiębiorstwami - odwrotnie niż w krajach wysoko rozwiniętych (KWR);

3. tymczasem blisko $80 \%$ polskich innowacji jest opartych na własnych pomysłach i rozwiązaniach powstałych w przedsiębiorstwach. Polskie firmy więc za mało korzystają z osiagnięć jednostek naukowych; to m.in. dlatego nasze innowacje techniczne reprezentują relatywnie niski poziom nowoczesności;

4. około $60 \%$ nakładów finansowych na badania i rozwój pochodzi z kasy publicznej (budżet państwa plus fundusze unijne), zaś przedsiębiorstwa partycypują w nieco ponad $1 / 3$ - też odwrotnie niż w KWR. Nie znaczy to, oczywiście, że należy obniżać nakłady publiczne na $\mathrm{B}+\mathrm{R}$, wręcz odwrotnie:

16 Dane statystyczne do każdego z wymienionych punktów można znaleźć w dwóch najnowszych publikacjach GUS [2017, 2018]. 
jeśli mamy osiagnąc wymarzoną średnią unijna, powinny one szybko rosnać, przy czym nakłady prywatne (przedsiębiorców) powinny rosnąć jeszcze szybciej. Publiczne wydatki powinny być „holownikiem” prywatnych inwestycji w B+R;

5. również odwrotnie niż w KWR, udział nakładów na badania podstawowe jest u nas wyższy niż na badania stosowane. Tymczasem te drugie znajdują się „bliżej rynku” niż te pierwsze. Także i w tym przypadku nie chodzi o ograniczanie nauk podstawowych, lecz o szybki wzrost nauk stosowanych.

Jednakże naszą największą bolączką jest tu niezwykle niski - ponad dwukrotnie niższy od średniej unijnej - udział nakładów na badania i rozwój w PKB Polski, który w 2016 r. wyniósł 0,97\% PKB, czyli znów spadł poniżej 1\% [GUS, 2017]. Wytyka to nam np. Jeffrey Sachs [2018] w wywiadzie dla noworocznego numeru tygodnika „Polityka”.

\section{Aktualne wyzwania}

Na tym tle można sformułować trzy wyzwania pod adresem polityki innowacyjnej w Polsce do roku 2020 [Jasiński, 2014]. Punktem wyjścia do dalszych prac nad instrumentarium działalności innowacyjnej powinno być założenie, że wspieranie potencjału badawczo-rozwojowego (nakładów, zatrudnienia, aparatury) w przedsiębiorstwach to obecnie najważniejsze wyzwanie pod adresem narodowego systemu innowacji w Polsce.

Musi temu towarzyszyć zdecydowane usprawnienie współpracy między nauką a biznesem, w tym podmiotów działających na styku obu sektorów (to drugie wyzwanie). Dzięki różnym formom partnerstwa nastapić powinna intensyfikacja procesów transferu technologii i dyfuzji innowacji. W rezultacie będzie lepsza absorpcja wyników prac $\mathrm{B}+\mathrm{R}$ w gospodarce, czyli większy popyt na nowe rozwiązania naukowo-techniczne ze strony firm.

Trzecim wyzwaniem jest usprawnianie organizacji i funkcjonowania jednostek wchodzących w skład sektora $\mathrm{B}+\mathrm{R}-$ tak, żeby sektor ten oferował obfita podaż (ofertę) nowoczesnych rozwiązań naukowo-technicznych, bardziej odpowiadających potrzebom przedsiębiorstw zorientowanych na innowacje, i aktywniej występował z własną inicjatywa pod adresem przedsiębiorców. Nie będzie to jednak możliwe bez równoczesnego, szybkiego i znacznego wzrostu publicznych nakładów na badania i rozwój.

Jak widać, są to nieco inne wyzwania niż rekomendacje wypracowane w ramach Foresight'u. Zreszta podobne wyzwania pod adresem naszej polityki naukowo-technicznej formułują również m.in. Świadek i Weresa, a także instytucje międzynarodowe, np. OECD. Zdaniem Świadka [2017], w przypadku krajów słabiej rozwiniętych, w tym Polski, polityka ta powinna być nakierowana na podnoszenie zdolności absorpcyjnych przedsiębiorstw, przyciaganie nowych technologii z KWR oraz usprawnianie dyfuzji innowacji. Z kolei Weresa [2014] uważa, że przed polityką w krajach Europy Środkowo-Wschodniej stoją takie główne wyzwania, jak: konieczność jej większego umiędzynarodowienia, poprawa jakości zasobów ludzkich i lepsza 
komercjalizacja wiedzy. Natomiast OECD [2012] sformułowała pod adresem Polski następujące wyzwania: (1) zwiększenie wydatków na badania i rozwój oraz poprawa efektywności badań publicznych poprzez lepsze ich finansowanie i zarządzanie, (2) stymulowanie B+R w sektorze przedsiębiorstw i rozwój przedsiębiorczości, (3) poprawa kwalifikacji i efektywności pracowników badawczych oraz (4) rozwój gospodarki opartej na wiedzy.

\section{Podsumowanie}

W okresie transformacji polskiej gospodarki polityka państwa w stosunku do nauki i techniki przeszła pozytywną ewolucję: od wiary w rolę niewidzialnej ręki rynku do wspierania innowacji w nowoczesny sposób. Jednakże cały czas falowała trochę jak wzburzone morze, przechodząc przez sześć faz/etapów tej ewolucji. Towarzyszył temu niedostateczny wysiłek finansowy państwa w sferze $B+R$ i innowacji. W rezultacie, polityka ta okazała się małoskuteczna. Teraz powinna sprostać poważnym wyzwaniom - jeżeli Polska ma doganiać, a nie tylko gonić kraje wysokorozwinięte pod względem poziomu innowacyjności gospodarki narodowej. W tym celu powinniśmy czerpać z doświadczeń Unii Europejskiej, a nie tylko oczekiwać dodatkowych darmowych funduszy z Brukseli.

\section{Literatura}

Aho E. (ed.), 2006, Creating an innovative Europe, European Commission, Brussels.

Bal-Woźniak T., 2012, Innowacyjność w ujeciu podmiotowym, PWE, Warszawa.

Bendyk E., 2010, Polska 2020: Spojrzenie zprayszłości, NPF, Warszawa.

Ciborowski R., 2012, Modele rozwoju innowacyjnego, [w:] Jasiński A.H., Ciborowski R. (red.), Ekonomika $i$ zarzqdzanie innowacjami, Wydawnictwo Uniwersytetu w Białymstoku, Białystok.

Ciborowski R., 2016, Międzynarodowy transfer technologii a innowacyjność krajów Europy Środkowo-W schodniej, PTE, Białystok.

Czerniak J., 2013, Polityka innowacyjna w Polsce, Difin, Warszawa.

Dodgson M., Bessant J., 1996, Effective innovation policy: A new approach, International Thomson Business Press, London.

EC, 2006, Putting knowledge into practice: A broad-based innovation strategy for the EU, $\operatorname{COM}(2006)$, “European Innovation”, Special Issue, November 2006.

EC, 2010, European innovation scoreboard, Brussels.

EC, 2011, Europe 2020, European Commission, COM(2010), Brussels.

EC, 2016, European innovation scoreboard, Brussels.

Edquist C., 1994, Systems of innovation: Technologies, institutions and organizations, Pinter, London.

Etzkowitz H., Leydesdorff L., 1995, The triple helix: University-industry-government relations, "EASST Review", no. 1. 
Guellec D., van Pottelsberghe B., 2003, The impact of public R\&D expenditure on business R\&D, "Economics of Innovation and New Technology", no. 3.

GUS, 2016, Nanka i technike w roku 2015, Warszawa.

GUS, 2017, Dĩatalność innowacyjna przedsiębiorstw przemystonych w latach 2014-2016, Warszawa.

GUS, 2018, Nauka i technika w roku 2016, Warszawa.

GUS, kolejne lata, Roczniki z serii Nauka i technika, Warszawa.

Janasz W. (red.), 2010, Innowacje w strategii rozwoju organizacii w Unii Europejskiej, Difin, Warszawa.

Janasz W., 1999, Innowacyjne strategie rozwoju przemystu, Fundacja Uniwersytetu Szczecińskiego, Szczecin.

Janasz W. (red.), 2011, Innowacje w zrównoważonym rožwoju organizacji, Difin, Warszawa.

Janasz W., Kozioł-Nadolna K., 2011, Innowacje w organizacji, PWE, Warszawa.

Jasiński A.H., 1997, Innowacje $i$ polityka innowacyjna, Wydawnictwo Uniwersytetu w Białymstoku, Białystok.

Jasiński A.H., 2006, Innowacje i transfer techniki w procesie transformacji, Difin, Warszawa.

Jasiński A.H., 2018, Innowacyjność polskiej gospodarki a fundusze unijne: Cજy POIG coś pomógl?, „Studia i Prace WNEiZ US”, Szczecin.

Jasiński A.H., 2014, Innowacyjność w gospodarce Polski: Modele, bariery, instrumenty wsparcia, Wydawnictwo Naukowe Wydziału Zarządzania UW, Warszawa.

Klincewicz K., 2008, Polska innowacyjność: Analiza bibliometrycz̨na, Wydawnictwo Naukowe Wydziału Zarządzania UW, Warszawa.

Kozioł K., 2007, Innowacyjność polskich przedsiebiorstw pržemystonych na tle doswiadczeń Unii Europejskiej, Uniwersytet Szczeciński.

Linsu K, 1999, Learning and innovation in economic development, E. Elgar, Cheltenham.

Malmberg A., Maskell P., 2010, An evolutionary approach to localized learning and spacial clustering, [in:] The handbook of evolutionary economic geography, E. Elgar, Cheltenham.

Marciniak S., 2010, Innowacyjność i konkurencyjność gospodarki, Wydawnictwo Beck, Warszawa.

Moszkowicz K., 2001, Procesy innowacyjne w polskim przemyśle, Wydawnictwo AE we Wrocławiu, Wrocław.

MRR, 2007, Narodowa Strategia Spójności na lata 2007-2013, Ministerstwo Rozwoju Regionalnego, Warszawa.

OECD, 1997, Choices of policy instruments, OECD Publishing, Paris.

OECD, 2012, Science, technology and industry outlook, 2012, OECD Publishing, Paris.

Okoń-Horodyńska E., 1998, Narodowy system innowacji w Polsce, Wydawnictwo AE, Katowice.

Romer P.M., 1990, Endogenous technological change, "Journal of Political Economy", no. 5. Sachs J., 2018, Wywiad dla tygodnika, „Polityka”, nr 4.

Stoneman P., 1987, The economic analysis of technology policy, Oxford University Press, Oxford.

Świadek A., 2017, Krajony system innowacii w Polsce, CeDeWu, Warszawa.

Tidd J., Bessant J., 2011, Zarzqdzanie innowacjami, Oficyna Wolters Kluwer, Warszawa. 
Ustawa z dnia 30 maja 2008 r. o niektórych formach wspierania działalności innowacyjnej, Dz. U. 2008 nr 116 poz. 730.

Ustawa z dnia 12 stycznia 1991 r. o Komitecie Badań Naukowych, Dz. U. 1991 nr 8 poz. 28.

Ustawa z dnia 8 października 2004 r. o zasadach finansowania nauki, Dz. U. 2004 nr 238 poz. 2390.

Weresa M., 2012, Systemy innowacyjne we wspótczesnej gospodarce swiatowej, PWN, Warszawa.

Weresa M., 2014, Polityka innowacyjna, PWN, Warszawa. 